\title{
Weather and Climate Tools for Florida Agricultural Producers ${ }^{1}$
}

Christian L. Miller, and Kati Migliaccio²

\section{Introduction}

Florida is in a hot and humid region of the country which, on average, receives an abundance of both sunlight and rainfall. The average annual rainfall total for the state is approximately 53 inches (Fraise et al., 2004). Accessibility to current weather information and long-term climatic data is valuable for many reasons, such as aiding farmers in planning the appropriate schedules for planting, irrigation, and harvest (Jagtop et al., 2002). The purpose of this document is to familiarize Floridas agricultural producers with some of the weather and climate tools that are available via the internet.

\section{Weather Tools}

Weather relates to hourly or daily observations for a specific location. Weather reports generally include measurements of temperature, wind speed, humidity, precipitation, and barometric pressure.

\section{Florida Automated Weather Network}

The Florida Automated Weather Network, or FAWN, was initiated in response to demand from the

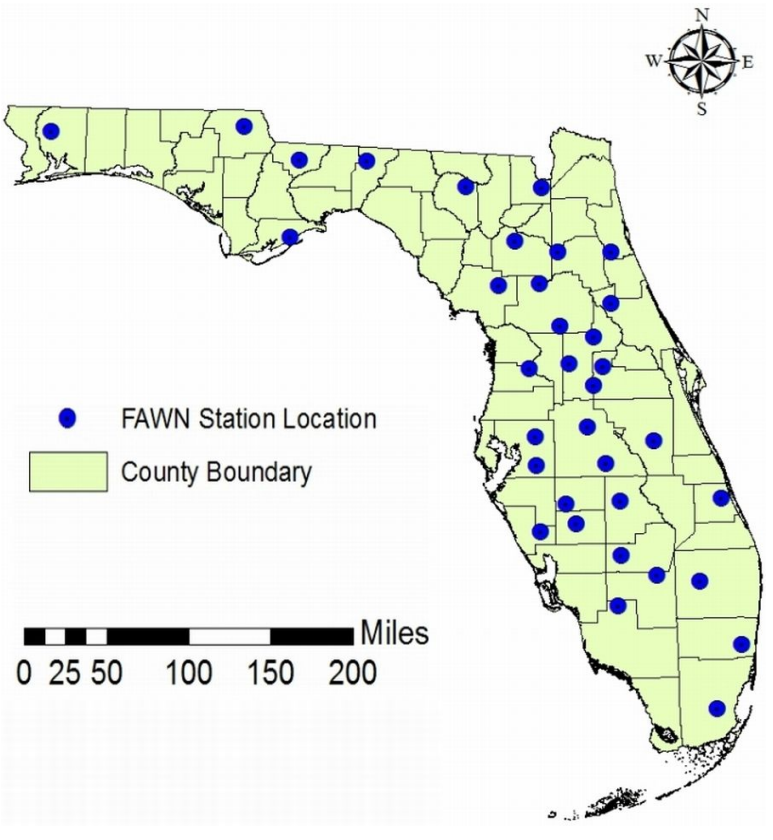

Figure 1. Locations of current FAWN stations

agricultural community after the National Weather Service discontinued their support for agricultural weather services in 1996. FAWN, which is made possible through the continued support of various state agricultural organizations and industry associations, provides current weather observations

1. This document is AE440, one of a series of the Agricultural and Biological Engineering Department, Florida Cooperative Extension Service, Institute of Food and Agricultural Sciences, University of Florida. Original publication date November 2008. Visit the EDIS Web Site at http://edis.ifas.ufl.edu.

2. Christian L. Miller, extension agent, Miami-Dade County Cooperative Extension, Homestead; Kati Migliaccio, assistant professor, Tropical Research and Education Center (TREC) Homestead; Florida Cooperative Extension Service, Institute of Food and Agricultural Sciences, University of Florida, Gainesville, FL 32611.

The Institute of Food and Agricultural Sciences (IFAS) is an Equal Opportunity Institution authorized to provide research, educational information and other services only to individuals and institutions that function with non-discrimination with respect to race, creed, color, religion, age, disability, sex, sexual orientation, marital status, national origin, political opinions or affiliations. U.S. Department of Agriculture, Cooperative Extension Service, University of Florida, IFAS, Florida A. \& M. University Cooperative Extension Program, and Boards of County Commissioners Cooperating. Larry Arrington, Dean 
through a system of statewide automated weather monitoring stations to a variety of users throughout the state of Florida (Parsons and Beck, 2004).

Visitors to the FAWN Website are also able to access archived data, which can be viewed in the form of tables and graphic presentations.

(http://fawn.ifas.ufl.edu/).

Of particular interest to agricultural producers are the evapotranspiration (ET) tables. This tool provides daily reference ET values for all of the FAWN monitoring locations. Reference ET tables are useful for determining irrigation schedules for local agricultural production. For more information on how to use reference ET for irrigation scheduling, please see Irmak and Haman (2003) and Clark et al. (2002)

In order to access the FAWN reference ET information:

\section{Log on to the FAWN site -} http://fawn.ifas.ufl.edu;

2. Mouse over "Tools" on the top men bar and select "Evapotranspiration (ET)" from the dropdown menu;

3. Scroll down the page to find the ET values for the site closest to you; and

4.Find visual presentations of the last 14 days worth of data by selecting the station from the drop down menu on the ET page and clicking the "Go" button.

\section{Other tools include:}

- Minimum Overnight Temperature - gives an accurate estimate of the nightly minimum low temperature based on temperature and dew point at nightfall.

- Alter-Rater Calculator - Assists in the timing of fungicide applications for brown spot in citrus.

- Citrus Irrigation Tools - Irrigation tables and schedules for Florida citrus.

\section{Interactive Weather Information Network}

The Interactive Weather Information Network (IWIN) is housed on the National Weather Services (NWS) Website (http://iwin.nws.noaa.gov/iwin/fl/fl.html ) and provides up to date weather observations for various locations around Florida. Use a computer mouse to select a desired station to get the most recent weather conditions. Updated satellite and radar imagery can also be accessed from this site

\section{Climate Tools}

Climate is the average weather condition over a specific region over a long period of time. This can correspond to either averages of a season or averages of years for a specific geographic area. Long-term climatic data is useful for weather forecasting and can be useful when planning various weather-dependent endeavors. For example, a farmer might consult climate data when determining the best time period for planting crops.

\section{ENSO cycle}

El Niño-Southern Oscillation (ENSO), most commonly referred to simply as either "el Niño" or "la Niña", is an interaction between the Earths oceans and atmosphere (Fraise et al., 2004). These interactions are not fully understood, but are the most well known source of widespread variations in world-wide climate from year to year. Current ENSO cycle updates can be found at the NWS Climate Prediction Center Website

(

http://www.cpc.ncep.noaa.gov/products/precip/ CWlink/MJO/enso.shtml).

This ENSO phenomenon is best known by a rise or fall in sea surface temperatures in the eastern Pacific Ocean. When the temperature is higher than average, the phenomena is known as el Niño, when the temperature is lower than average it is called la Niña (Figure 2). Generally, during El Niño years, there are more frequent low pressure systems from late fall through early spring. This leads to increased storm cycles and lower than average temperatures over the entire state of Florida. There may also be an increase in heavy rains which could lead to localized 
flooding and an increase in severe weather such as tornadoes and damaging windstorms.

During la Niña years, Florida generally encounters fewer low-pressure systems in the fall and winter, and as a result much drier and warmer than average conditions overall. La Niña conditions may also lead to increased chances of drought and wildfires, and also a greater chance of freezing weather, but currently those interactions are poorly understood and impossible to predict (Jagtap et al., 2002).
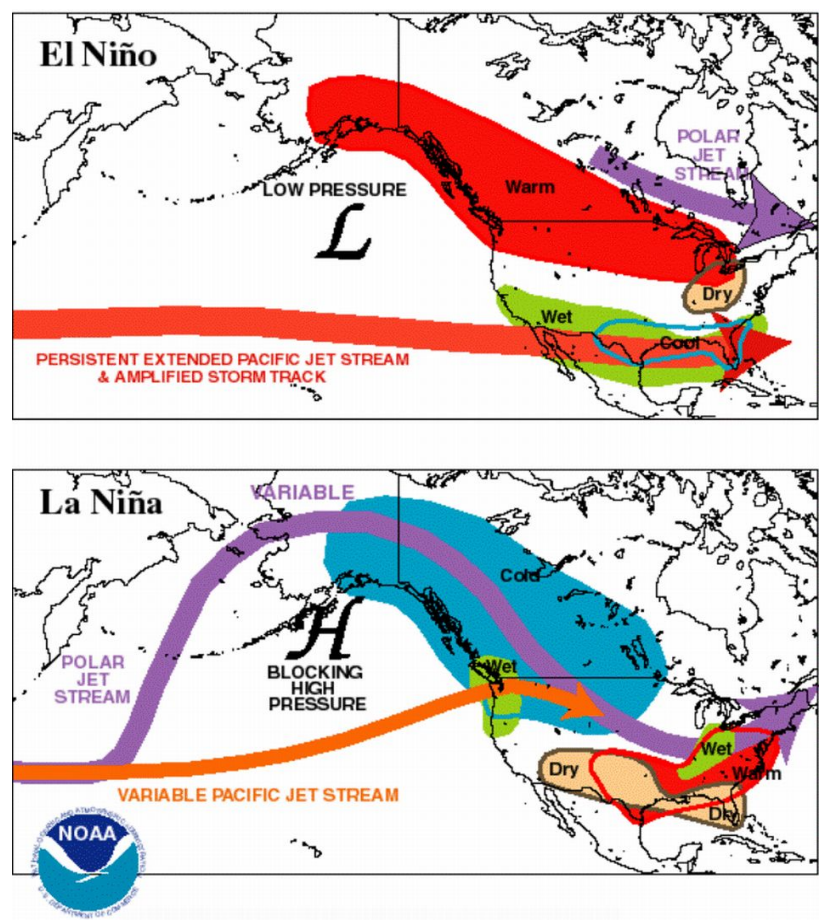

Figure 2. Typical January-March weather anomalies and atmospheric circulation during moderate to strong EI Niño \& La Niña. Credits: Climate Prediction Center/NCEP/NWS

\section{Drought}

Drought is a normal and recurring climatic feature which occurs worldwide but with variation depending on the region of occurrence. However, in the simplest terms, a drought results from a deficiency of rainfall over an extended period of time which results in a shortage of water for some activity, group, or the environment. Even though Florida, on average, receives over 50 inches of rainfall on an annual basis, variations in annual precipitation exist and droughts have historically been part of climatic cycles (Black, 1993). Currently, there are no viable tools for predicting where or when drought will occur. However, current drought conditions, including outlooks and drought assessment tools can be found on the National Weather Service Website: http://www.srh.noaa.gov/mfl/precip.php.

\section{AgroClimate}

AgroClimate (http://www.agroclimate.org/ ) is a web based product from the Southeast Climate Consortium that is used to provide the latest seasonal climate forecasts and tools (http://agroclimate.org/tools/) to help producers understand and plan for potential climate variations in the Southeastern United States (Fraisse et al., 2007). Some of the tools that may be of particular interest to Florida growers include:

- Freeze Risk Forecast - This tool consists of maps showing probabilities of a given county to experience freezing temperatures at least once during the winter season.

- Yield Risk Forecast -The crop yield forecast helps growers analyze yield potential based on ENSO forecast, planting date, soil type, and management strategies such as irrigation schedules and fertilization rates.

- Climate Risk - This tool allows the user to search average rain fall totals based on: monthly distributions, probabilities of distribution and exceedance, and the past 5 years of archived data. These totals can all be sorted based on climatic conditions (i.e. El Niño vs. La Niña).

\section{Conclusion}

Since crop yield drives the bottom line for production agriculture, finding ways to increase yield is a subject of continual research as new varieties of crops, improvement of management strategies, and more efficient agrochemicals are constantly being developed. However, given all the advancements in science and technology, producers are often constrained by forces beyond their control.

Most incidences of crop failure in the United States are due to either too little or too much rain (Ibara and Hewitt, 1999). If a means of predicting climatic variations were available to farmers, it 
would give them a tool to better prepare to meet these challenges as they arise.

The possible opportunities for using predictable climate variations to modify farm management strategies, especially agricultural impacts associated with ENSO, offer considerable economic potential. Practical applications for climate tools include the ability to select the appropriate varieties of field crops, anticipate purchase of fungicides, and anticipate needs of additional fertilizers, herbicides, or livestock feeds in advance in order to avoid higher prices. In the past, Florida growers have reported altering management practices due to ENSO predictions. Farmers in South Florida reported clearing state-operated drainage canals and reforming potato fields for better drainage, after learning about the expected 1997-98 El Nino. A Florida strawberry producer also indicated using climate forecasts when deciding what varieties to plant (Jagtop et al., 2002).

The Florida Department of Agriculture attributed $\$ 165$ million in losses to agriculture and forestry in Florida due to the 1997-98 El Niño event (Jagtop et al., 2002). It was estimated by Adams et al. (1995) that the benefit of ENSO-based forecasts to agriculture could exceed $\$ 100$ million dollars annually in the Southeastern US. Although we currently dont have precise tools for predicting long-term climate impacts on Florida agriculture, incorporating currently available weather tools as part of an overall farm management plan is encouraged, and the potential benefits of their use are readily apparent.

\section{References}

Adams, R.M., K.J. Bryant, B.A. McCarl, D.M. Legler, J. OBrien, A. Solow, R. Weiher, 1995.

Value of improved long-range weather information. Contemporary Economic Policy 13:10-19.

Black, R.J.. Florida Climate Data. 1993. Institute of Food and Agricultural Sciences (IFAS Publication EES-5), Florida Cooperative Extension Service.

Gainesville, FL.

Clark, G.A., A.G. Smajstrla, and F.S. Zazueta. 2002. Atmospheric Parameters Which Affect
Evapotranspiration. (IFAS Publication CIR-822), Florida Cooperative Extension Service. Gainesville, FL.

Fraisse, C., D. Zierden, N. Breuer, J. Jackson, and C. Brown. 2004.Climate Forecast and Decision Making in Agriculture. (IFAS Publication ABE-352), Florida Cooperative Extension Service. Gainesville, FL.

Fraisse, C., J. O. Paz, and C. M. Brown. 2007. Using Seasonal Climate Variability Forecasts: Crop Yield Risk. (IFAS Publication Cir 1498), Florida Cooperative Extension Service. Gainesville, FL.

Ibarra, R. and Hewitt, T. 1999. Utilizing crop insurance to reduce production risk. (IFAS Publication FE-198), Florida Cooperative Extension Service. Gainesville, FL.

Irmak, S. and D.Z. Haman. 2003. Evapotranspiration: Potential or Reference? (IFAS Publication ABE-343) Florida Cooperative Extension Services. Gainesville, FL.

Jagtap, S.S., J.W. Jones, P. Hildebrand, D. Letson, J.J. OBrien, G. Podesta, D. Zierden, and F. Zazueta. 2002. Responding to Stakeholders Demands for Climate Information: From research to applications in Florida. Agricultural Systems. 74:3 pp 415-30.

Parsons, L. and H. Beck. 2004. Weather Data for Citrus Irrigation Management. (IFAS Publication HS950) Florida Cooperative Extension Services. Gainesville, FL. 